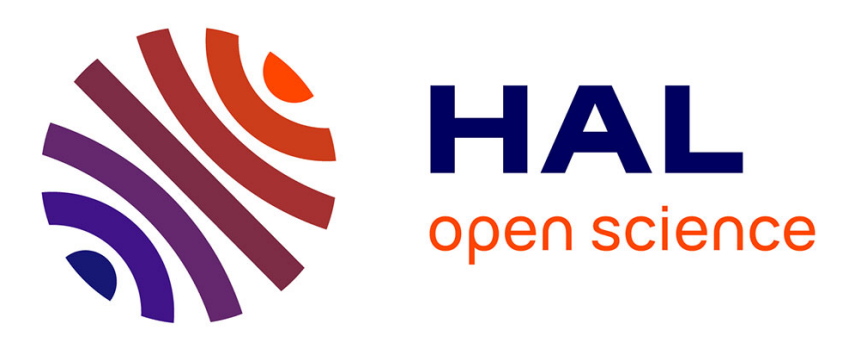

\title{
Quantitative study of volatiles in a model system by a headspace technique
}

\author{
Elisabeth Guichard, Violette Ducruet
}

\section{To cite this version:}

Elisabeth Guichard, Violette Ducruet. Quantitative study of volatiles in a model system by a headspace technique. Journal of Agricultural and Food Chemistry, 1984, 32 (4), pp.838-840. 10.1021/jf00124a036 . hal-01594107

\section{HAL Id: hal-01594107 \\ https://hal.science/hal-01594107}

Submitted on 2 Jun 2020

HAL is a multi-disciplinary open access archive for the deposit and dissemination of scientific research documents, whether they are published or not. The documents may come from teaching and research institutions in France or abroad, or from public or private research centers.
L'archive ouverte pluridisciplinaire HAL, est destinée au dépôt et à la diffusion de documents scientifiques de niveau recherche, publiés ou non, émanant des établissements d'enseignement et de recherche français ou étrangers, des laboratoires publics ou privés. 
do not measure DHA may substantially underestimate vitamin $\mathrm{C}$. However, since the relative contribution of DHA to vitamin $C$ activity is not constant, the error due to nonestimation of DHA will not remain constant for any produce.

Registry No. DHA, 490-83-5; ascorbic acid, 50-81-7. LITERATURE CITED

AOAC. "Official Methods of Analysis", 13th ed.; Association of Official Analytical Chemists: Washington, DC, 1980; p 746. Davidek, G. J.; Grundova, K.; Velisek, J.; Janicek, G. Lebensm.-Wiss. Technol. 1972, 5, 213.
Finley, J. W.; Duang, E. J. Chromatogr. 1981, 207, 449.

Hughes, R. E. Biochem. J. 1956, 64, 203.

Lu, Y. C.; Chou, Y. C. Chin. Med. J. (Peking, 1932-1966) 1955, 73, 206.

Mills, M. B.; Damron, C. M.; Roe, J. H. Anal. Chem. 1949, 21, 707.

Roe, J. H.; Oesterling, M. J. J. Biol. Chem. 1944, 152, 511.

Rose, R. C.; Nahrwold, D. L. Anal. Biochem. 1981, 114, 140.

Wimalasiri, P.; Wills, R. B. H. J. Chromatogr. 1983, 256, 368.

Received for review July 1, 1983. Revised manuscript received January 19, 1984. Accepted March 2, 1984.

\title{
Quantitative Study of Volatiles in a Model System by a Headspace Technique
}

\author{
Elisabeth A. Guichard* and Violette J. Ducruet
}

\begin{abstract}
A test solution was prepared with 16 pure compounds belonging to various chemical classes and representative of those found in fruits and fermented beverages aroma. These volatiles were extracted during $24 \mathrm{~h}$ by nitrogen entrainment associated with continuous Freon 11 liquid extraction in an apparatus similar to the one described by Rapp and Knipser. Analysis of the recovered material was done by quantitative gas chromatography. Reproducibility of the method is good; coefficients of variation are below $15 \%$. Polar compounds such as alcohols, 4-ethylphenol, and lactones are not quantitatively recovered $(2-10 \%)$ as they are badly entrained with nitrogen. Unstripped compounds are recovered by back-extraction of the remaining test solution. Apolar compounds such as terpene hydrocarbons are completely entrained with nitrogen but are partially lost during the extraction procedure. Losses are below $20 \%$.
\end{abstract}

In the recent years, $\mathrm{N}_{2}$ entrainment associated with trapping on a porous polymer has been widely used to study the aroma of wines and fruits (Jennings et al., 1972; Noble, 1978; Williams and Strauss, 1977; Murray, 1977). Minor components often critically important to aroma have been detected by this method while they could not have been revealed by an equilibrium method such as liquid and piston displacement (Williams et al., 1978).

The porous polymers have the common advantage of possessing minimal retention for ethanol as well as water, but some specific drawbacks have been detected for each of them. Tenax has been extensively used to study wines volatiles (Bertuccioli and Viani, 1976; Noble, 1978; Noble et al., 1980). Because of its high thermal stability, heavy compounds were quickly desorbed but its low specific area could create a fast saturation of the trap (Butler and Burke, 1976; Brown and Purnell, 1979). Porapack and Chromosorbs have higher sampling capacity, but high boiling compound recoveries are incomplete due to their low thermal stability (Williams et al., 1978). These different selectivities of porous resins induce distortion in the composition of collected headspace volatiles. A last common drawback is the necessity of conditioning the trap before and after each sample collection.

To avoid the disadvantages associated with the use of an adsorbent, Rapp and Knipser (1980) have proposed a method that combines $\mathrm{N}_{2}$ entrainment and volatile trap-

Institut National de la Recherche Agronomique, Laboratoire de Recherches sur les Arômes, 21034 Dijon Cedex, France. ping by Freon 11 continuous extraction. Williams (1982) advocated this method to collect volatiles of fruit or alcoholic beverages, but this procedure has been questioned by Novak $(1981,1982)$. However, recently Simpson and Miller (1983) and Guichard (1984), respectively, applied this technique with success to the study of Riesling wine and raspberry.

Rapp and Knipser evaluated reproducibility of their method for terpenoid components and others volatiles of interest for Moriot Muscat wine aroma. In this work we have tested this method with a model system of pure compounds belonging to various chemical classes of interest for fruit or fermented beverage aroma. Recovery of the pure compounds and the losses associated with this method were investigated by quantitative estimations of the constituents in the aroma extract and in the remaining test solution. The reproducibility of the techniques was determined for each compound.

\section{MATERIALS AND METHODS}

Model Solution. The test solution was made by adding $1 \mathrm{ppm}(\mathrm{v} / \mathrm{v})$ of each pure compound to a $10 \%$ aqueous ethanol solution. Water was purified on $\mathrm{XAD}_{2}$ resin as described by James et al. (1981).

Extraction Procedure. The apparatus as proposed by Rapp and Knipser to collect volatiles was slightly modified: the tip of the collecting funnel was fitted with a fritted disc (porosity 2), which creates a dispersion of solvent in the sample.

Eight-hundred milliliters of test solution was placed in a flask kept in a water bath at $25^{\circ} \mathrm{C}$. Volatiles were entrained by purified nitrogen swept at the rate of 50 